\title{
TRAINING CONFERENCE EMPHASISES COMMUNICATION
}

his year's training conference for more than 300 trainee public health physicians in the UK emphasised the necessity of clear communication for adequate public health function. The conference, at Blackpool in early April, was organised by the Faculty of Public Health Medicine (formerly Community Medicine) of the Royal Colleges of Physicians of the UK.

The conference used groups of trainees to identify the key communication issues in their daily work written or oral, with public health colleagues or clinicians, the community or the media. Oral presentations of completed work were examined within groups for their clarity and stimulus.

Much of the conference concerned communication from the college to trainees about revised examination arrangements for both Part I and Part II of the fellowship. In the UK both parts of the fellowship are awarded by examination, Part II requiring the submission of completed projects by the trainees and orals pertaining to them. A similar pattern is followed in New Zealand College.

Non-medical associates are to be accepted into the UK Faculty of Public Health Medicine. The faculty fulfils in the UK many of the functions of the more multidisciplinary Public Health Association in Australia and the Australasian Epidemiological Association.

In the recently revised NHS, which emphasises the role of Area-equivalents in planning and buying rather than providing health care, Public Health Medicine has received an immense boost. It is seen as the key discipline underpinning needs identification, comparison of inter-Area health statistics, observation and measurement of health outcomes and evaluation.

The UK Faculty of Public Health Medicine is about to embark on a national goals and targets exercise for the UK akin to the Australian Better Health and New Zealand efforts and the corporate interest in goals-based planning receiving emphasis in NSW.

The dramatic highlight of the conference was when, following their noses, president Walter Holland and the vice-president inspected the kitchens of the conference hotel - and declared them unfit. That day's conference banquet was organised at another Blackpool hotel with great haste - a fine example of rapid policy formulation and implementation following hard on epidemiological inquiry - and good communication!

Stephen Leeder

Professor of Community Medicine

University of Sydney

\section{TETANUS (ICD-9 037)}

etanus cases continue to be notified in NSW.

Nine were notified in the period 1982-1990 two of them in 1990.

The 1990 cases were a 66-year-old man from New England and an 81-year-old woman from the North Coast Regions.

During 1989/1990 one separation from hospital due to tetanus was recorded in the Inpatient Statistics Collection.

Tetanus Toxoid first became available to Australian servicemen during World War II. Routine use of tetanus toxoid began in 1954. The cases of tetanus notified in 1990 give cause for concern that all people born before 1953 who did not serve in the armed forces may not be immunised against tetanus.

The NSW Health Department recommends that doctors review the immunisation status of all patients. Primary immunisation can be started at any age.

\section{FIGURE 2}

\section{TETANUS NOTIFICATIONS}

NSW, 1982-1990

Number

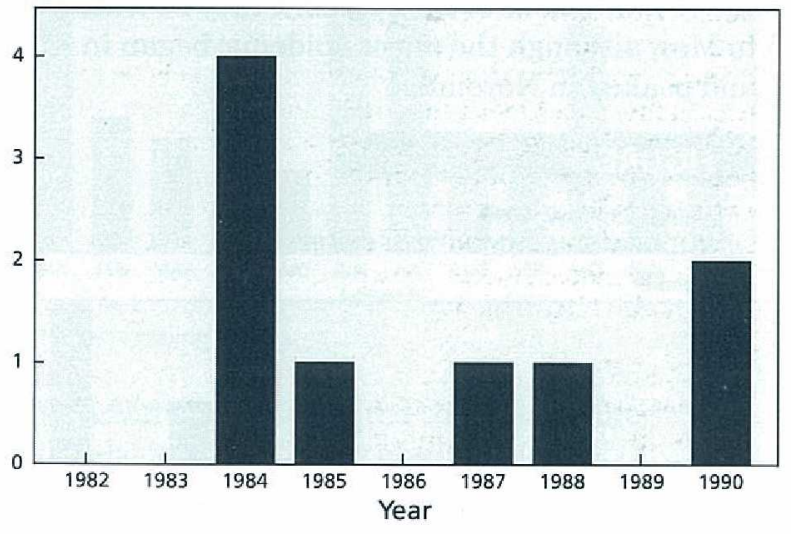

Source: NSW Infectious Disease Database.

\section{MEASLES (ICD-9 055)}

Preventing measles has been the focus of concerted public health initiatives over the past three years through health promotion and immunisation campaigns. There is evidence, however, that the coverage of measles immunisation is less than optimal. Estimates of immunisation coverage during the recent Hunter epidemic indicate that only $85-90 \%$ of the population of NSW are immune to measles.

The three-year periodicity of measles has yet to be altered by the mass immunisation program in place since 1968. The greatest number of measles 


\section{Infectious Diseases}

\section{Continued from page 56}

notifications received by the NSW Health Department was recorded in 1990. This was in part due to active surveillance of cases and formal notifications initiated by Public Health Units in the absence of notifications by medical practitioners.

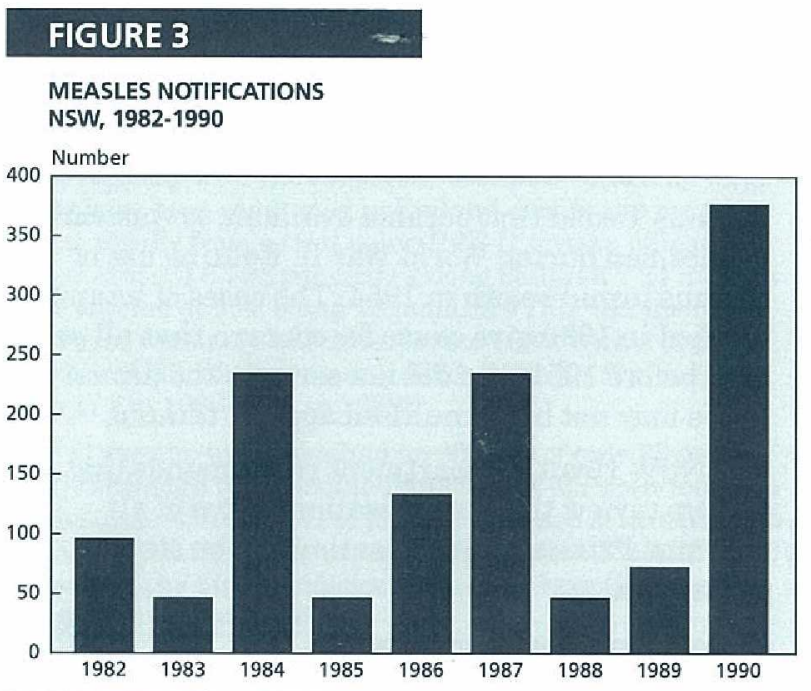

Source: N5W infectious Disease Database

A major measles outbreak was recorded in 1990.

Early indications of the epidemic may be traced back to May, although the major epidemic began in August and peaked in November.

\section{FIGURE 4}

MEASLES, NSW, 1990

NOTIFICATIONS BY MONTH OF ONSET

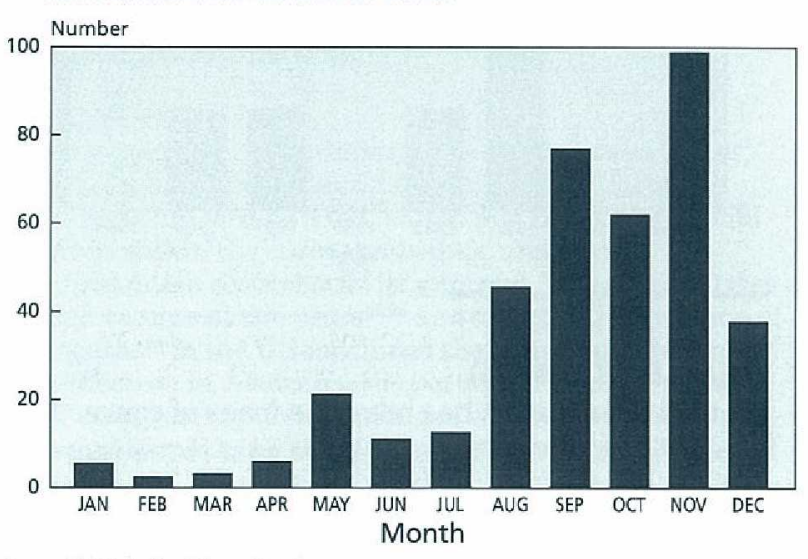

Source: NSW Infectious Disease Database.

The centre of the epidemic was the Hunter Area. Neighbouring regions, New England and North Coast, also reported higher than average rates.

In 1990379 cases of measles were notified. The State average for measles was 6.5 cases $/ 100,000$ population. Males and females were affected equally. The preponderence of cases in under 15-year-olds highlights the importance of schools as the site

\section{FIGURE 5}

MEASLES NOTIFICATIONS

NSW, 1990, BY AHS/REGION

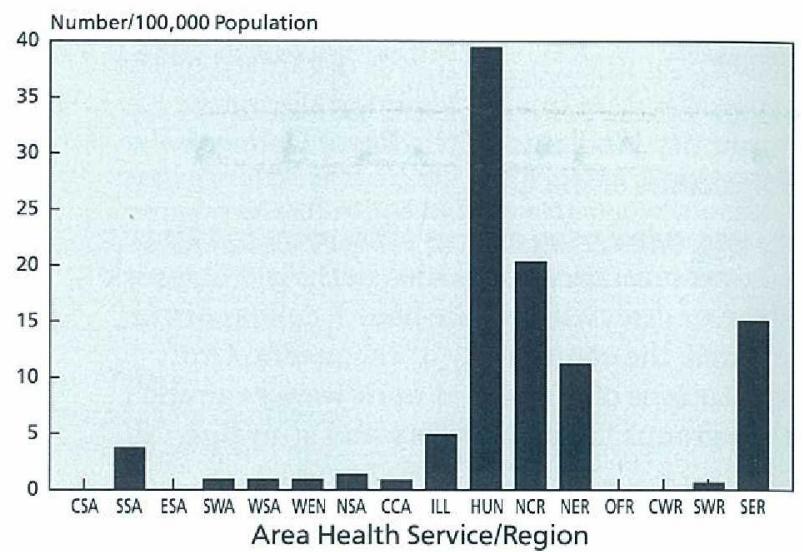

Source: NSW Infectious Disease Database.

of disease transmission. Legislation to require documentation of immunisation at the time of school-entry is envisaged in 1992.

The National Health and Medical Research Council is considering the issue of a second dose of measlesmumps-rubella vaccine. NSW data would support this initiative, as most of the 1990 cases would have been prevented by compliance with the existing immunisation protocol.

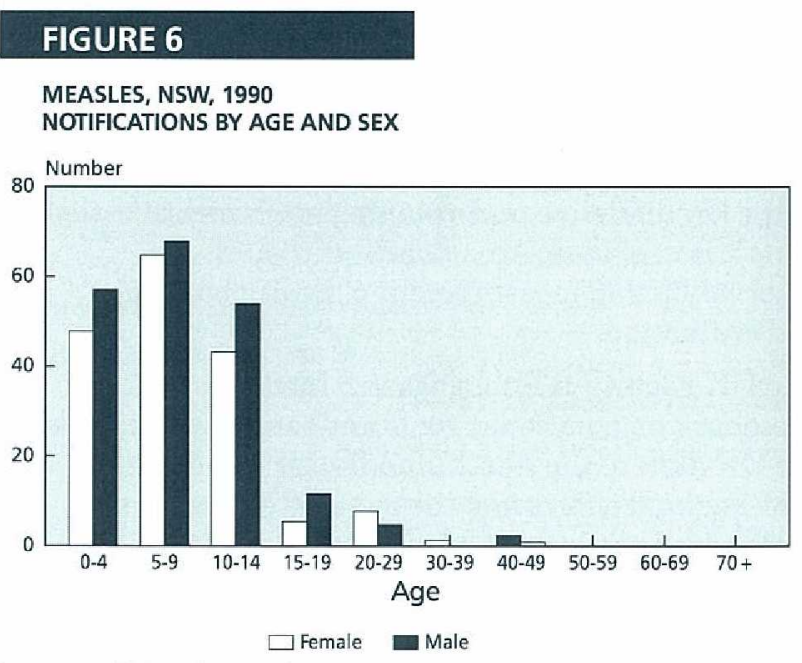

Source: N5W Infectious Diséase Datábase.

In 1989/1990 71 separations from hospital due to measles were recorded in the Inpatient Statistics Collection.

The prospect of eradicating measles is still an unachievable goal. The aim of the NSW immunisation program against measles is a high level of control, consistent with World Health Organisation programs. 


\section{Infectious Diseases}

\section{Continued from page 57}

This situation requires increased compliance with notification requirements by medical practitioners, and an ability to respond to outbreaks in a timely and efficient manner. Staff of several Public Health Units have responded effectively to measles outbreaks throughout the year.

\section{PERTUSSIS (WHOOPING COUGH) (ICD-9 033)}

Pertussis cases were notified from 15 of the 16 Area Health Services and Regions. No distinctive winter pattern could be discerned from 1990 notifications, and total notifications were lower in 1990 than for 1989 .

Cases are predominantly in pre-school children, but school-age children still constitute enough cases to raise concern about the place of schools in the transmission of this disease.

\section{FIGURE 7}

PERTUSSIS, NSW, 1982-1990 NOTIFICATIONS

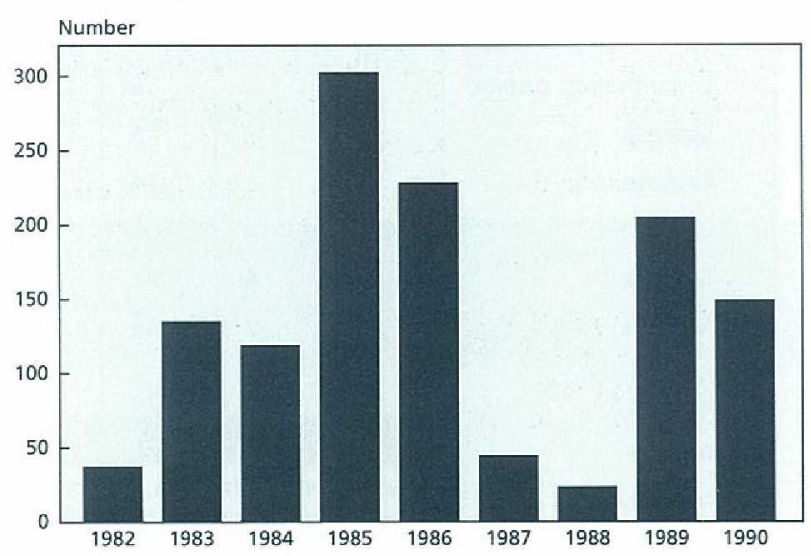

Source: NSW Infectious Disease Database.

\section{FIGURE 8}

PERTUSSIS NOTIFICATIONS, NSW, 1990 BY AHS/REGION

Number $/ 100,000$ Population

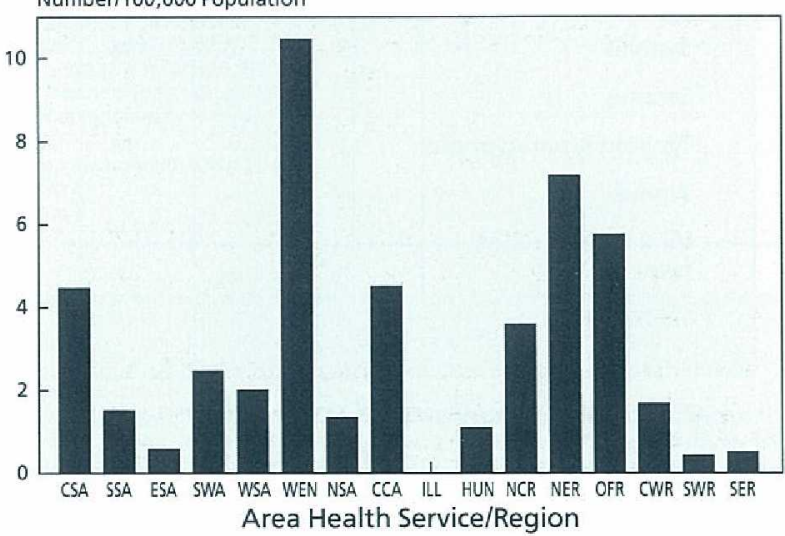

source: NSW Infertious Dispase Database.

\section{FIGURE 9}

PERTUSSIS, NSW, 1990

NOTIFICATIONS BY AGE AND SEX

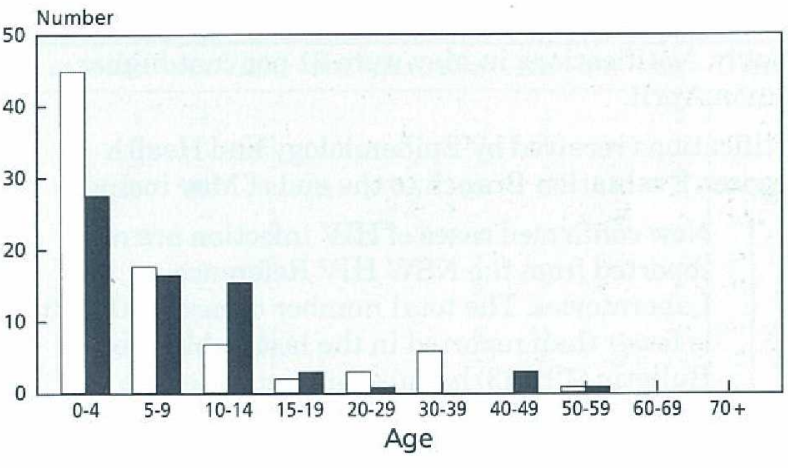

$\square$ Female $\quad$ Male

Source: NSW Infectious Disease Database.

\section{FIGURE 10}

PERTUSSIS, NSW, 1990

NOTIFICATIONS BY MONTH OF ONSET

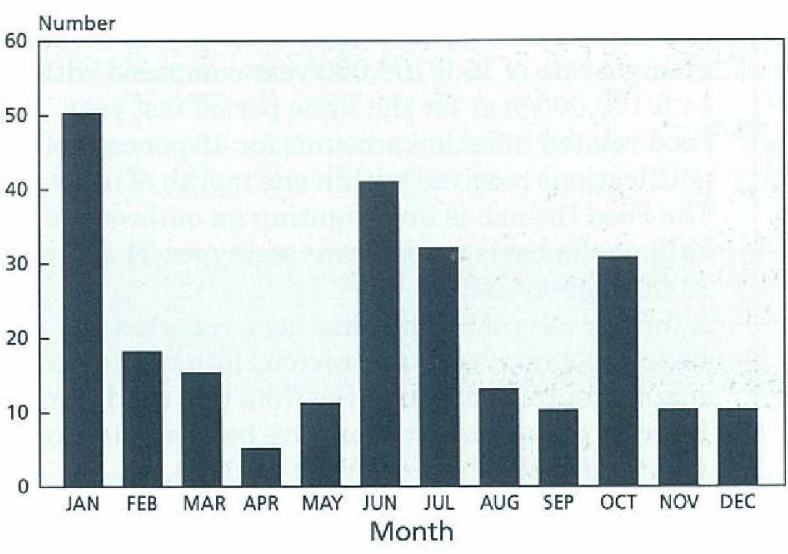

Source: NSW Infectious Disease Database.

The NH\&MRC has considered the issue of pre-school pertussis booster, but in the absence of proof of pertussis transmission from school into homes with unimmunised infants, it has deferred its decision.

In 1990152 cases of pertussis were notified. The State average for pertussis was 2.6 cases $/ 100,000$ population.

In 1989/1990 510 separations from hospital due to pertussis were recorded in the Inpatient Statistics Collection.

The pertussis vaccine still has a poor public image, and is the least effective of all vaccines routinely used. The basis for lack of confidence in this vaccine must play a large role in the persistence of widespread outbreaks of disease.

Notification of cases plays a crucial role in the prevention of further cases.

1. De Cean G, Levy M. Pertussis notification. Med J Aust 1990;153:503. 


\section{NOTIFICATIONS}

nfectious diseases notifications are now received on the Infectious Diseases Database System (IDDS) and efforts are being made to ensure they are reported quickly. Notifications in May were 21 per cent higher than in April.

Notifications received by Epidemiology and Health Services Evaluation Branch to the end of May include:

New confirmed cases of HIV infection are now reported from the NSW HIV Reference

Laboratories. The total number of cases $(10,243)$ is fewer than reported in the last Public Health Bulletin $(12,833)$ because previous positive test results have now been excluded (repeat tests) for all reference laboratories including St Vincent's. Sub-totals for the various risk-group categories have also been adjusted as a result of this improved matching process. As further refinements to the St Vincent's matching algorithm that identifies repeat tests on individuals will be implemented, subsequent figures will need to be adjusted again.

Of the total of 10,243 identified positives to date, 299 new cases have been reported this year giving a rate of 15.9/100,000/year compared with $14.5 / 100,000 / y e a r$ for the same period last year. Food-related infection accounts for 43 per cent of notifications received within one month of onset. The Food Branch is investigating an outbreak of Salmonella bovis morbificans serotypes 21 and 23 throughout NSW.

- A further case of tetanus has been reported. A 49-year-old man with no previous immunisation against tetanus is recovering from this condition. The risk groups for tetanus have been previously described in the Bulletin (Vol $2 \mathrm{Pp} 3,13,26$ ). NHMRC recommends that everyone receive tetanus immunisation.

- Measles cases continue to be notified. Many notifications are received too late for effective responses to be mounted. We urge medical practitioners to telephone notifications if a case is suspected ${ }^{1}$, and to confirm all index cases serologically. The Hunter Area Health Service notified measles at an annual rate of 15/100,000 this year. This compares with a rate of 39/100,000/year during 1990.

The rate of syphilis notification in Orana and Far West is $41 / 100,000$ (not 4.1/100,000, as reported in Vol 2, Number 5).

- Hepatitis $\mathrm{C}$ has been notified by only seven Areas and Regions. Laboratories are encouraged to notify all confirmed cases of Hepatitis $\mathrm{C}$ to Public Health Units.

New South Wales has a rate of 1.4/100,000/year. The Central Sydney Area Health Service notifies Hepatitis C at a rate of $10.8 / 100,000 /$ year and the North Coast Region notifies at a rate of $5.6 / 100,000 /$ year.
TABLE 1

INFECTIOUS DISEASES

NOTIFICATIONS, NSW

Notifications to the

end of May 1991

\begin{tabular}{|c|c|c|c|c|}
\hline \multirow{3}{*}{ CONDITION } & \multicolumn{4}{|c|}{ Number of Cases Notified } \\
\hline & \multicolumn{2}{|c|}{ Period } & \multicolumn{2}{|c|}{ Cumulative } \\
\hline & $\begin{array}{l}\text { May } \\
1990\end{array}$ & $\begin{array}{l}\text { May } \\
1991\end{array}$ & $\begin{array}{l}\text { May } \\
1990\end{array}$ & $\begin{array}{l}\text { May } \\
1990\end{array}$ \\
\hline Acute viral hepatitis & 58 & 23 & 117 & 498 \\
\hline AIDS & 19 & N/A & ${ }^{*} 143$ & ${ }^{*} 77$ \\
\hline Arboviral infections & - & 2 & 64 & 295 \\
\hline Brucellosis & - & - & 2 & 2 \\
\hline Cholera & - & - & 1 & - \\
\hline Diphtheria & - & - & - & - \\
\hline Foodborne illness & $N / A$ & 35 & N/A & 1035 \\
\hline Gastroenteritis (instit.) & N/A & 1 & N/A & 24 \\
\hline Gonorrhoea & 44 & 5 & 159 & 113 \\
\hline $\begin{array}{l}\text { Haemophilus } \\
\text { influenza inf. }\end{array}$ & N/A & 5 & N/A & 43 \\
\hline HIV & N/A & N/A & 273 & *299 \\
\hline Hydatid disease & 2 & - & 2 & 1 \\
\hline Legionnaires' disease & 1 & - & 18 & 15 \\
\hline Leprosy & 1 & - & 5 & - \\
\hline Leptospirosis & 6 & 1 & 21 & 17 \\
\hline Listeriosis & N/A & - & N/A & - \\
\hline Malaria & 13 & 4 & 81 & 14 \\
\hline Measles & 21 & 2 & 36 & 85 \\
\hline $\begin{array}{l}\text { Meningococcal } \\
\text { infection }\end{array}$ & 12 & 3 & 28 & 21 \\
\hline Mumps & N/A & - & N/A & 2 \\
\hline $\begin{array}{l}\text { Mycobacterial } \\
\text { infections (NOS) }\end{array}$ & 42 & 8 & 206 & 56 \\
\hline Pertussis & 11 & - & 99 & 16 \\
\hline Plague & - & - & - & - \\
\hline Poliomyelitis & - & - & - & - \\
\hline Q fever & 10 & 4 & 66 & 36 \\
\hline Rubella & N/A & - & - & 7 \\
\hline Salmonella infection & 115 & 20 & 719 & 502 \\
\hline Syphilis & 35 & 6 & 136 & 176 \\
\hline Tetanus & - & 1 & - & 2 \\
\hline Typhoid \& paratyphoid & 2 & - & 14 & 36 \\
\hline Typhus & - & - & - & - \\
\hline $\begin{array}{l}\text { Viral haemorrhagic } \\
\text { fever }\end{array}$ & - & - & - & - \\
\hline Yellow fever & - & - & - & - \\
\hline
\end{tabular}

* Data January-April only 
TABLE 2

INFECTIOUS DISEASE NOTIFICATIONS,

BY HEALTH AREA \& REGION

JANUARY 1 TO MAY 31,1991

\begin{tabular}{|c|c|c|c|c|c|c|c|c|c|c|c|c|c|c|c|c|c|c|c|}
\hline CONDITION & CSA & SSA & ESA & sws & WSA & WEN & NSA & $\mathrm{CCA}$ & ILL & HUN & $\mathrm{NCR}$ & NER & OFR & CWR & SWR & SER & OTH & U/K & TOTAL \\
\hline AIDS & 9 & 2 & 33 & 3 & 7 & 3 & 10 & 4 & - & 1 & 3 & - & - & - & - & - & - & 2 & 77 \\
\hline Arboviral infection (NOS) & - & - & 8 & - & - & - & - & - & - & 6 & - & 131 & - & 4 & 30 & 2 & - & - & 181 \\
\hline $\begin{array}{l}\text { Brucellosis } \\
\text { Bestions }\end{array}$ & - & - & 2 & - & - & - & - & - & - & - & - & - & - & - & - & - & - & - & 2 \\
\hline Foodborne illness (NOS) & 25 & 35 & 309 & 43 & 77 & 78 & 50 & 6 & 14 & 39 & 185 & 70 & 12 & 26 & 50 & 2 & 14 & - & 1035 \\
\hline Gastroenteritis (instit.) & - & - & - & 4 & 9 & 6 & & - & & 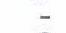 & - & 5 & - & - & - & - & - & - & 24 \\
\hline Gonorrhoea & - & 1 & 61 & 23 & 5 & - & 2 & - & 4 & 2 & 6 & 1 & 3 & - & 5 & - & - & - & 113 \\
\hline H Influe & - & - & - & - & 3 & 1 & 2 & - & 2 & - & - & 1 & - & - & 2 & - & - & - & 11 \\
\hline$H$ Influenzae infection (NOS) & - & - & 2 & - & 7 & 6 & - & - & 4 & 4 & - & - & - & - & 6 & 2 & - & - & 31 \\
\hline H Influenzae septicaemia & - & 1 & & & & - & - & - & - & - & - & - & - & - & - & - & - & - & 1 \\
\hline Hepatitis (NOS) & 3 & - & 90 & 28 & 107 & 6 & - & - & 8 & 18 & - & 21 & - & - & 6 & 14 & - & - & 301 \\
\hline Hepatitis A & 8 & 3 & - & 1 & 5 & $=$ & 7 & 1 & - & 4 & 3 & 1 & - & - & - & $\bar{z}$ & - & - & 33 \\
\hline Hepatitis B - acute & - & - & - & - & - & - & - & - & - & - & - & - & - & - & - & 2 & - & - & 2 \\
\hline Hepatitis B - carrier & 4 & 1 & 1 & - & 1 & - & - & - & - & - & - & $=$ & - & - & - & - & - & - & \\
\hline Hepatitis B - unspecified & 33 & 4 & 7 & 9 & 8 & 4 & 12 & - & 2 & 10 & 17 & 6 & 11 & - & - & - & 1 & - & 124 \\
\hline Hepatitis C & 12 & 1 & - & 1 & 3 & & 2 & - & - & - & 8 & 4 & - & - & - & - & - & - & 31 \\
\hline HIV infection & 21 & 6 & 71 & 8 & 17 & 2 & 18 & 1 & 2 & 10 & 8 & - & 1 & 1 & - & 1 & 2 & 130 & 299 \\
\hline Hydatid disease & - & - & - & - & - & - & - & - & - & - & - & 1 & - & - & - & - & - & - & 1 \\
\hline Legionnaires' disease & - & - & - & 4 & 5 & 2 & 1 & - & - & 2 & - & - & - & - & - & - & 1 & - & 15 \\
\hline Leptospirosis & - & - & - & - & - & - & 1 & - & - & 5 & 1 & 1 & 1 & - & 5 & - & 3 & - & 17 \\
\hline Malaria & - & - & - & - & 2 & 1 & 3 & - & 1 & 1 & 1 & & - & - & 3 & 2 & - & - & 14 \\
\hline Measles & 1 & - & - & 6 & 16 & 1 & 5 & - & 3 & 30 & 13 & 2 & - & - & 1 & 7 & - & - & 85 \\
\hline Meningococcal infection (NOS) & - & 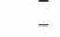 & - & 2 & 1 & 1 & - & - & 2 & 1 & 1 & 2 & - & - & - & - & - & - & 10 \\
\hline Meningococcal meningitis & $\overline{-}$ & 1 & - & - & - & - & 1 & - & - & 1 & 1 & - & - & - & - & 1 & - & - & 6 \\
\hline Meningococcal septicaemia & - & - & - & - & - & - & - & - & - & - & 4 & - & - & - & - & 1 & - & - & 5 \\
\hline Mumps & - & - & 1 & - & 1 & - & - & - & - & - & - & - & - & - & - & - & - & - & 2 \\
\hline Mycoba & 1 & 1 & - & - & 1 & - & 3 & - & - & - & - & - & - & - & - & - & - & - & 6 \\
\hline Mycobacteri & - & - & - & 7 & 16 & 5 & 1 & - & 8 & 1 & 3 & 2 & - & 3 & 1 & - & - & - & 47 \\
\hline Mycobacterial tuberculosis & 1 & 1 & - & - & & - & 1 & - & - & - & - & - & - & - & - & - & - & - & 3 \\
\hline $\begin{array}{l}\text { Pertussis } \\
\text { Pallis }\end{array}$ & - & - & 3 & 3 & 2 & 1 & 1 & - & - & 1 & 3 & - & 2 & - & - & - & - & - & 16 \\
\hline Q Fever & - & - & - & 1 & - & - & - & - & - & 2 & 7 & 15 & 5 & 3 & 3 & - & - & - & 36 \\
\hline Ross River fever & - & - & - & - & - & - & - & 2 & - & 1 & 11 & 71 & 20 & - & 4 & - & 5 & - & 114 \\
\hline Rubella & - & - & 4 & - & - & 1 & - & - & 1 & $i$ & - & - & - & - & - & - & - & - & 7 \\
\hline Salmonella infection (NOS) & 32 & 37 & 12 & 63 & 83 & 45 & 40 & 8 & 31 & 18 & 42 & 36 & 11 & 12 & 9 & 9 & 14 & - & 502 \\
\hline Syphilis & 9 & 4 & 26 & 31 & 12 & 2 & 5 & 1 & 4 & 8 & 31 & 10 & 19 & 4 & 2 & 1 & 7 & - & 176 \\
\hline Tetanus & & & & & 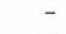 & - & - & - & - & & - & $\overline{2}$ & & - & - & 2 & - & - & $2^{2}$ \\
\hline Typhoid \& paratyphoid & 6 & 4 & 6 & - & - & 5 & 4 & 1 & 1 & 2 & - & 2 & 1 & - & - & - & 4 & - & 36 \\
\hline
\end{tabular}

\section{TABLE 3}

INFECTIOUS DISEASE NOTIFICATIONS,

BY HEALTH AREA \& REGION

MAY, 1991

\begin{tabular}{|c|c|c|c|c|c|c|c|c|c|c|c|}
\hline CONDITION & CSA & SSA & sws & WSA & WEN & ILL & HUN & NER & SWR & SER & TOTAL \\
\hline Arboviral infection (NOS) & - & - & - & - & - & - & 2 & - & - & - & 2 \\
\hline Foodborne illness (NOS) & 2 & 2 & - & 7 & 5 & - & 7 & 2 & 10 & - & 35 \\
\hline Gastroenteritis (instit.) & - & - & - & $\overline{-}$ & - & - & - & 1 & - & - & 1 \\
\hline Gonorrhoea & - & - & - & 5 & - & - & - & - & - & - & 5 \\
\hline H influenzae infection & - & - & $\bar{c}$ & 1 & 1 & 2 & - & - & 1 & $=$ & 5 \\
\hline Hepatitis (NOS) & - & - & 5 & 13 & - & - & 1 & 1 & - & 2 & 22 \\
\hline Hepatitis B - unspecified & 1 & - & - & - & - & - & - & - & - & - & 1 \\
\hline Leptospirosis & - & - & - & - & - & - & - & 1 & $=$ & $\overline{-}$ & 1 \\
\hline Malaria & - & - & - & - & - & - & - & - & 2 & 2 & 4 \\
\hline Measles & - & - & - & - & - & - & 2 & - & - & - & 2 \\
\hline Meningococcal infection (NOS) & - & - & - & - & - & 1 & - & 2 & - & - & 3 \\
\hline Mycobacterial infection (NOS) & - & - & 3 & 3 & - & - & - & - & 1 & - & 7 \\
\hline Mycobacterial tuberculosis & - & 1 & - & - & - & - & - & - & - & - & 1 \\
\hline Q Fever & & - & - & - & - & - & - & 3 & 1 & - & 4 \\
\hline Salmonella infection (NOS) & - & 1 & 1 & 10 & 4 & - & - & 4 & - & - & 20 \\
\hline Syphilis & - & - & - & 2 & - & 1 & - & 3 & - & - & 6 \\
\hline Tetanus & - & - & - & - & - & - & - & - & - & 1 & 1 \\
\hline To & 3 & 4 & 10 & 41 & 10 & 8 & 13 & 20 & 15 & 5 & 129 \\
\hline
\end{tabular}

Abbreviations used in this Bulletin:

CSA Central Sydney Health Area, ESA Eastern Sydney Health Area, SSA Southern Sydney Health Area, SWS South Western Sydney Health Area, WSA Western Sydney Health Area, WEN Wentworth Health Area, NSA Northern Sydney Health Area, CCA Central Coast Health Area, ILL IIIawarra Health Area, HUN Hunter Health Area, NCR North Coast Health Region, NER New England Health Region, OFR Orana \& Far West Health Region, CWR Central West Health Region, SWR South West Health Region, SER South East Health Region, IS Interstate, U/K Unknown, OS Overseas, NOS Not Otherwise Stated

Please note that the data contained in this Bulletin are provisional and subject to change because of late reports or changes in case classification. Data are tabulated where possible by area of residence and by the disease onset date and not simply the date of notification or receipt of such notification. 


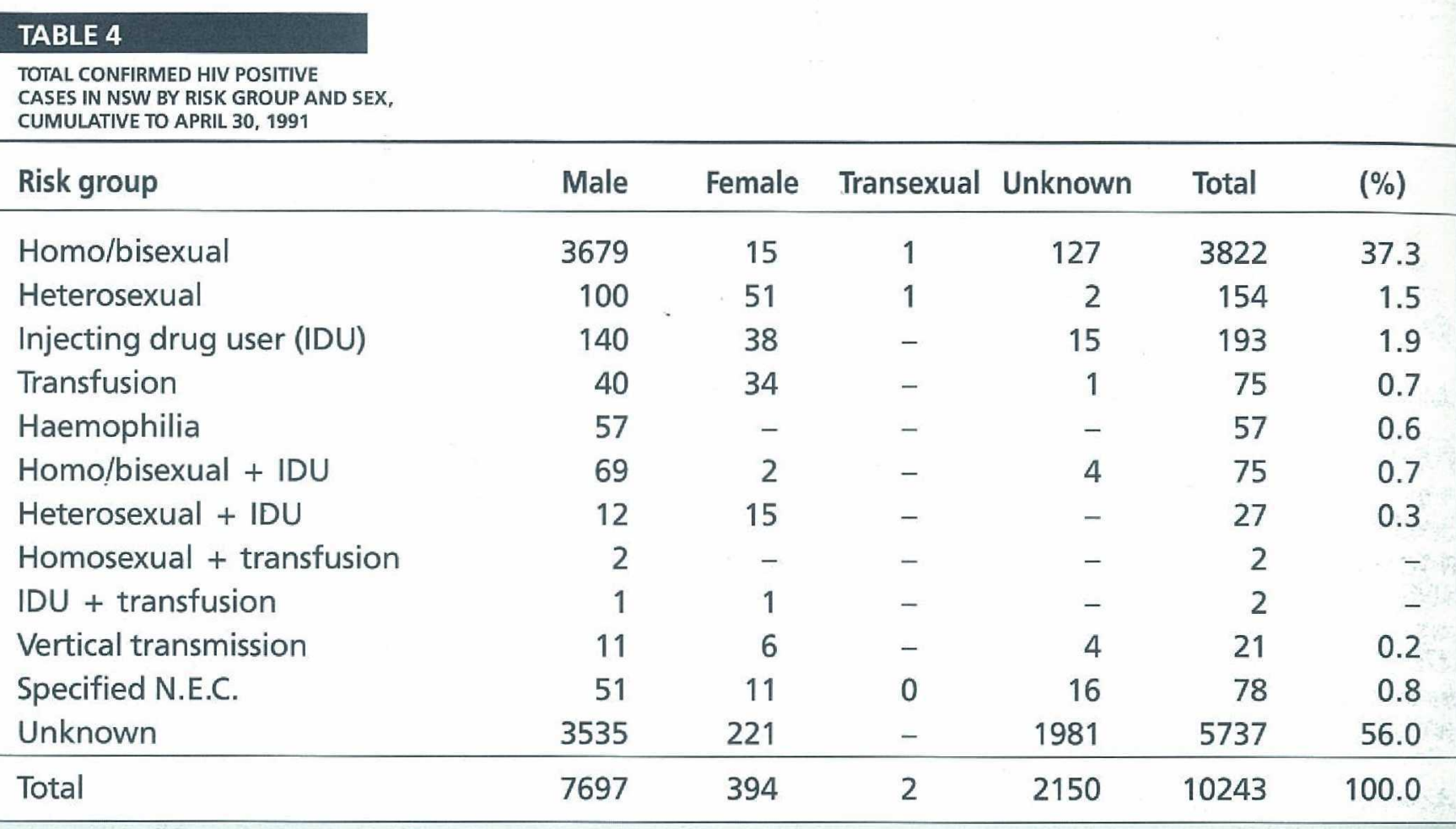

Data from Prince of Wales, Royal Prince Alfred, St Vincent's and Westmead hospitals all to 30/4/91 inclusive.

\section{New Director of Public HeALTH}

Dr John Beard has been appointed the North Coast Region's first full-time Medical Director of Public Health and has also accepted the appointment of Medical Officer of Health. During his three-year term as Director of Public Health, Dr Beard will be responsible for environmental health, health promotion, including Aboriginal health promotion, and a number of special programs, including AIDS/STDS, women's health and drug and alcohol. He will also co-ordinate public health policy and research for the Region.

\section{PUBLIC HEALTH EDITORIAL STAFF}

The Bulletin's editorial advisory panel is as follows: Dr Sue Morey, Chief Health Officer, Department of Health; Professor Stephen Leeder, Professor of Community Medicine, University of Sydney; Professor Geoffrey Berry,

Professor of Epidemiology \& Biostatistics, University of Sydney; Dr Christine Bennett, Associate Director, Service Development, Department of Health; Dr Michael

Frommer, Epidemiologist, Epidemiology \& Health

Services Evaluation Branch; Ms Jane Hall, Research Officer, Department of Community Medicine, Westmead Hospital; and Mr Michael Ward, Manager, Health Promotion Unit, Department of Health.

The editor is Dr George Rubin, Director, Epidemiology and Health Services Evaluation Branch, Department of Health, NSW.

Design and Production - Health Public Affairs Unit, Department of Health, NSW.

Please send your articles, news, comments or letters to Dr George Rubin — Locked Bag 961, North Sydney NSW 2059 or Fax (02) 3919293.

Suggestions for improving the content of the Bulletin are welcome. 